\title{
Het welbevinden van (vervroegd) gepensioneerden: De rol van onvrijwillig uittreden en het doorstarten in betaalde arbeid
}

Running title: 'Het welbevinden van (vervroegd) gepensioneerden'

Ellen Dingemans (correspondentie: Dingemans@ @idi.nl)

Promovenda, Nederlands Interdisciplinair Demografisch Instituut (NIDI), Den

Haag

Kène Henkens

Bijzonder Hoogleraar Pensioensociologie, Universiteit van Amsterdam (UvA)

Themaleider 'Werk en Pensioen', Nederlands Interdisciplinair Demografisch

Instituut (NIDI), Den Haag

Aantal woorden: 4.969

Aantal tabellen: 3

Aantal figuren: 2

Aantal bijlagen: 1

Dit artikel is een inkorting en bewerking van het artikel:

Dingemans, E., \& Henkens, K. Involuntary retirement, bridge employment, and satisfaction with life: A longitudinal investigation. Journal of Organizational Behavior 2013; Early View, 17 December 2013. DOI: 10.1002/job.1914. 


\section{Samenvatting}

Pensionering wordt steeds meer gezien als een proces waarin ouderen ook na (vervroegde) uittreding nog actief kunnen worden op de arbeidsmarkt in zogenoemde doorstartbanen. In het hier gepresenteerde onderzoek is nagegaan wat de consequenties van dit doorstarten zijn voor hoe gepensioneerden hun leven ervaren. De verwachting was dat de invloed van doorstarten op het welbevinden afhangt van de vrijwilligheid van het uittredeproces. Bovendien werden verschillen in welbevinden verwacht voor de verschillende motieven om door te starten na uittreden. De gegevens zijn ontleend aan paneldata voor Nederlandse oudere werknemers. De resultaten van de conditionele veranderingsmodellen laten zien dat een onvrijwillige beëindiging van de carrière samenhangt met een afname in welbevinden ten opzichte van vrijwillig gepensioneerden. Doorstarten blijkt echter dit negatieve effect te kunnen compenseren. De resultaten bevestigen ook dat ouderen die graag door wilden starten na pensioen maar niet succesvol bleken in het vinden van werk een afname in het welbevinden rapporteerden. Verder blijkt doorstarten om financiële redenen negatief te zijn voor het welbevinden, terwijl mensen die om intrinsieke redenen doorwerken en toename in welbevinden ervaren. De bevindingen van dit onderzoek dragen bij aan de kennis over hoe verschillende pensioentransities het leven na pensioen beïnvloeden.

\section{Trefwoorden:}

Welbevinden

Oudere werknemers

Pensionering

Onvrijwillig uittreden

Doorstartwerk 


\section{Summary}

Title: Retirees' well-being: The impact of involuntary retirement and bridge employment.

Retirement is increasingly recognized as a process that can take multiple forms and may contain a continuation in paid work after career exit, referred to as bridge employment. This research investigated the consequences of bridge employment for well-being of older adults during the transition to retirement. Bridge employment was assumed to compensate for the negative impact of involuntary career exit on well-being in later life. Furthermore, well-being was expected to be influenced by the different intentions and motives for taking bridge jobs. We used panel data on Dutch retirees. The results of the conditional change models demonstrate that involuntary retirement was detrimental for well-being, but engagement in a bridge job was found to mitigate this negative shock. In addition, older adults who searched for bridge jobs but were unable to find one reported decreased levels of well-being. Moreover, participation in bridge employment for financial motives was associated with decreases in well-being, whereas post-retirement working based on intrinsic motives was found to enhance the level of well-being. These results contribute to the understanding of the consequences of post-retirement work for late life well-being. This article is adapted from an article originally published in Journal of Organizational Behavior, doi: 10.1002/job.1914.

Key words:

Well-being

Older workers

Retirement

Involuntary retirement

Bridge employment 


\section{Inleiding}

Steeds meer ouderen keren na hun (vervroegde) pensionering terug op de arbeidsmarkt. De ouderen die op deze manier actief blijven na uittreden noemen we 'doorstarters' (1). Het gaat dan niet om mensen die vooruitlopend op hun pensioen minder uren gaan werken (deeltijdpensioen), maar het betreft een groep die na het uittreden de arbeidsloopbaan verlengt. Iets meer dan de helft gooit het over een geheel andere boeg en start door in totaal ander werk, terwijl anderen doorstarten in vergelijkbaar werk (2). Dit doorstarten is al langer een bekend fenomeen in bijvoorbeeld de Verenigde Staten, waar ongeveer zes op de tien ouderen betaalde arbeid verricht na pensioen. Maar ook in Nederland startte aan het begin van de eenentwintigste eeuw ongeveer twee op de tien (vervroegd) gepensioneerden door in betaald werk. Deze toegenomen diversiteit in werkpatronen aan het einde van de arbeidsloopbaan berust niet alleen op het individuele besluitvormingsproces, maar hangt ook samen met de mogelijkheden en restricties die oudere werknemers ervaren op de arbeidsmarkt (3). Dit kan grote gevolgen hebben voor het welbevinden na pensioen. In het onderzoek waarover hier wordt gerapporteerd is nagegaan of de vrijwilligheid van de pensioentransitie en het al dan niet doorstarten in betaalde arbeid na pensioen van invloed zijn op het welbevinden van gepensioneerden.

In de wetenschappelijke literatuur is veelvuldig aangetoond dat pensionering niet per se een vrijwillig afscheid van de arbeidsmarkt betekent. Schattingen laten zien dat ongeveer twee tot drie op de tien oudere werknemers de overgang naar pensioen als onvrijwillig ervaart. Een dergelijke transitie wordt vaak bepaald door druk vanuit de omgeving, bijvoorbeeld vanuit de organisatie, de partner of een verplicht leeftijdspensioen, of heeft te maken met gezondheidsproblemen. Hierdoor kunnen ouderen het gevoel hebben dat ze de controle over het eigen leven kwijt zijn, wat een negatieve invloed heeft op het welbevinden na pensioen $(4,5)$. Doorstarten in betaalde arbeid kan in dat geval een middel zijn om de overgang naar volledig pensioen nog even uit te stellen. Op die manier kan men de controle over het eigen leven en de timing van het afscheid van betaald werk weer terug in eigen hand nemen. Alhoewel de relatie tussen onvrijwillig pensioen en doorstarten vaak wordt gesuggereerd in de literatuur (6), is niet duidelijk of doorstarten inderdaad kan compenseren voor de negatieve invloed van onvrijwillig pensioen op welbevinden. Bovendien kan het zo zijn dat ook het wel of niet doorstarten een onvrijwillige component bevat. In de huidige tijd liggen banen niet voor het oprapen, en zeker niet voor oudere werknemers. De wens om door 
te starten na pensioen zal dus niet altijd gerealiseerd kunnen worden. Dit kan negatieve gevolgen hebben voor het welbevinden na pensioen.

Een ander onderbelicht aspect in de literatuur omtrent doorstarten is dat het actief zijn in doorstartwerk zowel positief als negatief kan uitpakken voor het welbevinden. Over het algemeen wordt doorstartwerk gezien als minder zwaar en veeleisend werk dat beter gecombineerd kan worden met de vrijetijdsbesteding in het privéleven (7). Het biedt gepensioneerden de mogelijkheid om actief te blijven en werk te blijven verrichten waar men plezier aan beleeft. Dit sluit aan bij de continuïteitstheorie die veronderstelt dat continuïteit in levenspatronen belangrijk is voor de stabiliteit in welbevinden (8). Bovendien profiteren doorstarters van de voordelen van betaald werk, zoals extra inkomen, sociale contacten en status. Doorstarten na pensioen wordt dan ook vaak positief geassocieerd met welbevinden. Maar ouderen kunnen zich ook gedwongen voelen om te blijven werken, bijvoorbeeld om financiële redenen (9). Ze zijn dan niet in staat invulling te geven aan de pensioentijd zoals ze dat graag zouden willen. In dat geval kan doorstarten een negatieve uitwerking hebben op het welbevinden na pensioen.

In het hier gerapporteerde onderzoek is de relatie tussen pensionering en welbevinden benaderd vanuit een dynamisch perspectief. In aanvulling op eerdere studies die uitsluitend aandacht hadden voor de overgang naar pensioen of het doorstarten na pensioen, hebben we expliciet de koppeling gemaakt tussen deze twee veranderingen in het werkdomein. Bovendien hebben we ons voor zowel de overgang naar pensioen als het doorstarten afgevraagd in hoeverre een zekere mate van controle over het eigen leven van invloed is op het welbevinden. De onderzoeksvraag was tweeledig. In welke mate hebben onvrijwillig pensioen en het niet slagen in de zoektocht naar doorstartwerk invloed op het welbevinden na pensioen? En, in welke mate kan het doorstarten na pensioen compenseren voor de mogelijk negatieve invloed van onvrijwillig pensioen op welbevinden? In de tweede plaats gaan we verder in op de motieven die mensen aandragen om door te starten na pensioen en in welke mate deze motieven een invloed hebben op het welbevinden. 


\section{Methode:}

\section{Data en onderzoeksgroep}

Het onderhavige onderzoek is gebaseerd op een panel studie naar het uittredegedrag van Nederlandse werknemers. Het beslaat de periode tussen 2001 en 2011 waarin verschillende vanzelfsprekendheden omtrent pensioen ter discussie werden gesteld (1). Vervroegde uittreding werd steeds meer ontmoedigd en langer doorwerken werd geleidelijk de norm. Aan het begin van de onderzoeksperiode in 2001 ging men in Nederland gemiddeld met vervroegd pensioen bij een leeftijd van 61 jaar. Deze gemiddelde effectieve pensioensleeftijd is in de loop van de tijd toegenomen tot 63 jaar in 2011 (10). Ook de arbeidsparticipatie na het vervroegde pensioen is in deze periode toegenomen van $16 \%$ in 2002 naar bijna een op de vier in 2007 (11).

In 2001 werd gestart met de eerste ronde van het NIDI Werk en Pensioen Panel. Alle werknemers van 50 jaar en ouder van drie grote Nederlandse ondernemingen en een aselecte steekproef van werknemers van 50 jaar en ouder bij de Rijksoverheid ontvingen een vragenlijst via de post $(\mathrm{N}=3.899)$. In totaal zonden 2.403 respondenten de vragenlijst retour. Deze respondenten werden daarna twee keer opnieuw benaderd voor een vervolgonderzoek. In 2007 reageerden 1.678 respondenten en in 2011 werden gegevens van 1.276 respondenten verzameld. Op alle drie de meetmomenten is informatie verzameld over demografische achtergrondkenmerken, de werksituatie en het welbevinden (voor meer informatie, zie 1).

De hier gepresenteerde analyses hebben betrekking op de 1.248 respondenten die in de tienjarige onderzoeksperiode de transitie naar pensioen hebben gemaakt en waarvoor gegevens over het welbevinden, de onvrijwilligheid van pensioen en het doorstartgedrag beschikbaar waren. Het overgrote deel van deze respondenten heeft gebruik gemaakt van een regeling om vervroegd uit te treden (gemiddelde vervroegde pensioenleeftijd was 59 jaar). Diegenen die tot 65 jaar hebben doorgewerkt (ongeveer $5 \% ; \mathrm{N}=57$ ) hebben in ongeveer de helft van de gevallen te maken gehad met een onvrijwillige pensioentransitie door het bereiken van de verplichte pensioenleeftijd, terwijl anderen op die leeftijd de transitie als vrijwillig hebben ervaren. Het panelkarakter van de data maakt het mogelijk om de werknemers te volgen in het uittredeproces en daarbij ook rekening te houden met de situatie voor pensioen. Voor iedere respondent is daarom het tijdstip van pensionering bepaald (tussen meetmoment één en twee of tussen meetmoment twee en drie). Het meetmoment vlak voor de 
pensionering is meegenomen als de voormeting en informatie over het pensioneringsproces is verkregen vanuit de eerste meting na pensioen.

\section{Meetinstrumenten}

Welbevinden - Om het welbevinden van de oudere werknemers voor en na hun pensioen in kaart te brengen is op ieder meetmoment gebruik gemaakt van drie stellingen (12): (i) Mijn leven is ideaal in de meeste opzichten, (ii) Mijn levensomstandigheden zijn uitstekend, en (iii) De belangrijkste dingen die ik van het leven verwacht, heb ik tot nu toe gekregen. Men kon op een 5-puntsschaal aangeven in hoeverre men het 'helemaal eens' (1) of 'helemaal oneens' (5) was met deze stellingen. De antwoorden op de drie vragen zijn vervolgens gespiegeld. De gemiddelde score op de drie vragen vormt de schaal voor welbevinden, waarbij hogere waarden dus duiden op een hoger welbevinden (Cronbachs alfa per opeenvolgend meetmoment: $0,71,0,74$, en 0,73 ).

Vrijwilligheid van pensioen - Gepensioneerde respondenten is gevraagd of zij het vertrek bij de oude werkgever hebben ervaren als vrijwillig of onvrijwillig. De antwoordopties waren: (i)

ja, geheel vrijwillig, (ii) nee, deels onvrijwillig, en (iii) nee, geheel onvrijwillig. In de analyses maken we gebruik van een dummy variabele waarbij vrijwillig pensioen de referentiegroep is en de percepties van deels en geheel onvrijwillig pensioen zijn samengevoegd tot de categorie voor onvrijwilligheid.

Doorstarten na pensioen - In het onderzoek is aan de respondenten de volgende vragen gesteld: (i) Hebt u sinds u gestopt bent bij [bedrijf / overheid] geprobeerd betaald werk te vinden?, en (ii) Hebt u sinds u bent gestopt met werken nog betaalde werkzaamheden verricht? In beide gevallen kon men antwoorden met 'ja' of 'nee'. We hebben de antwoorden gecombineerd tot een variabele met de volgende categorieën: 'volledig pensioen en niet meer gezocht naar doorstartwerk', 'volledig pensioen en niet succesvol in het vinden van doorstartwerk', en 'actief in doorstartwerk'. Sommige respondenten zijn wel actief geweest in doorstartwerk, maar waren op het moment van meting daarmee gestopt. Deze respondenten worden beschouwd als volledig gepensioneerd, maar we hebben in de analyses wel rekening gehouden met het doorstartwerk in het verleden door het opnemen van een dummy variabele. 
Vervolgens is aan de doorstarters gevraagd naar hun belangrijkste motief om door te starten: 'ik had het geld nodig', 'ik vond het leuk', 'ik verveelde me', 'voor de sociale contacten', en 'anders'. Omdat slechts tien respondenten hebben aangegeven dat verveling het voornaamste motief was om weer te gaan werken, is deze groep samengevoegd met de 'anders' categorie. Verder is er een categorie aangemaakt voor de groep die een missende waarde had op deze variabele.

Overige determinanten - In dit onderzoek wordt gecontroleerd voor persoonlijke factoren (leeftijd, geslacht, gezondheid, en de verwachte financiële situatie na pensioen), de samenstelling van het huishouden (partnerstatus en het hebben van kinderen) en de werkomgeving voor pensioen (tevredenheid met de baan, leidinggevende positie, niveau van de baan en tijd sinds het afscheid van de baan) (zie Bijlage voor meer informatie over de gebruikte meetinstrumenten).

\section{Analyses}

De invloed van de pensioentransitie op het welbevinden is nagegaan met behulp van conditionele veranderingsmodellen (13). Het welbevinden na pensioen is hier geschat op basis van het welbevinden van voor de overgang naar pensioen, de meetinstrumenten ten aanzien van de pensionering en het doorstartgedrag, en de overige determinanten. Er werden twee modellen geschat. In het eerste model is gekeken naar het belang van de vrijwilligheid van uittreden en het doorstartgedrag in de verklaring van welbevinden. We hebben hiervoor informatie over de vrijwilligheid van het uittreden (twee categorieën) en het doorstartgedrag (drie categorieën) gecombineerd in één variabele met zes categorieën. Op die manier zijn verschillen in welbevinden tussen de verschillende pensioneringstransities direct te toetsen. In het tweede model is gekeken naar de specifieke motieven voor doorstartwerk. Door het relatief kleine aantal doorstarters in de steekproef was het helaas niet mogelijk om deze motieven voor doorstartwerk te onderzoeken in interactie met de vrijwilligheid van pensioen.

Deze multivariate analyses geven de verschillen tussen groepen ouderen weer in de verandering in welbevinden tijdens het uittredeproces. Als aanvulling op deze resultaten presenteren we twee figuren die de ongewogen gemiddelde scores op welbevinden van voor en na het uittreden voor de verschillende groepen weergeven. Op die manier wordt inzicht verschaft in de individuele veranderingen in welbevinden tijdens de overgang naar pensioen. 
-- Tabel 1 ongeveer hier -- 


\section{Resultaten}

Tabel 1 geeft een beschrijving van de samenstelling van de onderzoeksgroep. Ondanks dat het welbevinden licht daalt na pensioen, kunnen we concluderen dat ouderen gemiddeld genomen overwegend positief zijn over hun leven, met een score van bijna 4 op een schaal van 1 tot 5 . Verder blijkt dat bijna drie op de tien ouderen uit de onderzoeksgroep de overgang naar (vervroegd) pensioen als onvrijwillig heeft ervaren. De meerderheid, ongeveer tachtig procent, keert na pensioen niet meer terug op de arbeidsmarkt. Een deel hiervan had dat echter wel gewild, maar was niet succesvol in de zoektocht naar doorstartwerk. Twee op de tien gepensioneerden heeft na (vervroegde) uittreding een doorstart gemaakt in betaald werk. Ruim de helft (53\%) van hen deed dat omdat ze het werk leuk vinden. Een veel kleiner deel werkte na pensioen uit financiële redenen $(15 \%)$ of omdat men de sociale contacten mist $(10 \%)$.

-- Tabel 2 ongeveer hier --

De resultaten van de multivariate analyses zijn weergegeven in tabel 2 en tabel 3. In tabel 2 wordt nagegaan in welke mate onvrijwillig (vervroegd) pensioen en het maken van een doorstart invloed hebben op het welbevinden na pensioen, wanneer we rekening houden met de overige determinanten. Uit de resultaten komt naar voren dat het niet succesvol zijn in het vinden van doorstartwerk na zowel vrijwillig als onvrijwillig uittreden zorgt voor een afname in het welbevinden ten opzichte van vrijwillig gepensioneerden die niet meer actief hebben gezocht naar werk. Bovendien vinden we dat onvrijwillig volledig pensioen negatief is voor het welbevinden wanneer we dit vergelijken met de groep die vrijwillig de overgang naar pensioen heeft gemaakt. Het veronderstelde compenserende effect van doorstartwerk na onvrijwillig uittreden komt ook uit de resultaten naar voren. Enerzijds, hebben ouderen die onvrijwillig met pensioen zijn gegaan en niet meer actief zijn geworden op de arbeidsmarkt daadwerkelijk een lager niveau van welbevinden na pensioen vergeleken met onvrijwillig gepensioneerden die succesvol zijn doorgestart op de arbeidsmarkt $(\mathrm{t}=-1,93, p=0,05)$. Anderzijds, blijkt dat de groep van onvrijwillig gepensioneerden in doorstartwerk niet afwijkt in de mate van welbevinden na pensioen van de groep die vrijwillig met pensioen is gegaan. 
In tabel 3 is het doorstartwerk verder uitgesplitst naar de motieven om te blijven werken. Allereerst komt ook uit deze tabel naar voren dat het niet kunnen vinden van doorstartwerk een negatief effect heeft op het welbevinden. Als we kijken naar de mensen die het wel is gelukt om door te starten dan zien we dat het doorwerken om financiële motieven gepaard gaat met een negatieve verandering in het welbevinden ten opzichte van volledig gepensioneerden, terwijl gepensioneerden die zijn doorgestart omdat men het werk leuk vond een toename in welbevinden ervaren. De overige categorieën voor doorstartwerk blijken niet van significante invloed op veranderingen in het welbevinden.

-- Figuur 1 en figuur 2 ongeveer hier --

Figuur 1 en 2 tonen voor verschillende categorieën van (vervroegd) gepensioneerden het gemiddelde niveau van welbevinden tijdens het uittredeproces. Allereerst bevestigt figuur 1 de compenserende werking van doorstarten na onvrijwillig uittreden voor het welbevinden na pensioen. Ook hier zien we dat onvrijwillig (vervroegd) gepensioneerden die niet zijn doorgestart op de arbeidsmarkt een afname in welbevinden ervaren, terwijl diegenen die onvrijwillig zijn uitgetreden en wel weer actief zijn geworden in betaald werk weinig tot geen verandering in welbevinden ervaren. In figuur 2 zien we vervolgens terug dat een financieel motief om door te starten gepaard gaat met een negatieve verandering in welbevinden tijdens het uittredeproces. Ouderen die doorstarten vanuit een intrinsieke motivatie lijken daarentegen een toename in welbevinden te ervaren. 


\section{Discussie}

Pensionering is niet langer een definitief afscheid van de arbeidsmarkt. In de plaats daarvan zien we dat steeds meer ouderen na (vervroegde) uittreding doorstarten in betaald werk. Een deel van de ouderen is in staat om hun voorkeur om al dan niet door te starten in de praktijk te brengen. Er zijn echter ook ouderen die zich in de overgang naar pensioen op enig moment belemmerd voelen. Allereerst kunnen we concluderen dat er een groep bestaat die bereid is door te werken, maar toch, onvrijwillig, volledig is gepensioneerd. Zij waren niet in staat om na hun uittrede de arbeidsloopbaan te continueren. Blijkbaar bestaan er barrières en hindernissen in de toegang tot werk op hogere leeftijd (14). Ten tweede laten de resultaten ook een groep 'onvrijwillige' doorstarters zien. Deze gepensioneerden voelden zich om financiële redenen genoodzaakt om door te werken. Zij ervaren het doorstartwerk wellicht niet als een geleidelijke overgang naar volledige pensioen, maar als een noodzaak het hoofd financieel boven water te houden.

De resultaten van dit onderzoek maken duidelijk dat deze diversiteit in intenties en motieven om door te starten na (vervroegd) pensioen gevolgen blijken te hebben voor het welbevinden. In sommige gevallen heeft doorstarten een positieve invloed op het welbevinden, bijvoorbeeld na onvrijwillig uittreden. Ouderen die zich gedwongen voelden om uit te treden en erin geslaagd zijn door te starten op de arbeidsmarkt hebben een hoger welbevinden dan de onvrijwillig gepensioneerden die niet zijn doorgestart in betaald werk. Dit ondersteunt het idee dat doorstartwerk een compenserende werking kan hebben na pensioen doordat het zorgt voor een zekere continuïteit in het werkdomein. Toch heeft het fenomeen doorstarten ook zijn negatieve uitwerkingen. Ouderen die ondanks hun zoektocht naar doorstartwerk niet in staat waren om betaald werk te vinden ervaren een afname in het welbevinden. Ook het onvrijwillig doorstarten op de arbeidsmarkt om financiële redenen gaat gepaard met een negatieve verandering in het welbevinden.

In tegenstelling tot de algemene opvattingen in de literatuur die doorstarten als een mogelijkheid zien om geleidelijk afscheid te kunnen nemen van de arbeidsmarkt, zien we dus dat doorstartwerk niet altijd positief uitpakt. Er blijkt een duidelijke tweedeling te bestaan. Enerzijds blijken doorstarters veelal intrinsiek gemotiveerd te zijn om op vrijwillige basis actief te blijven op de arbeidsmarkt. Omdat de doorstartbanen vaak minder veeleisend zijn en minder tijd in beslag nemen (1), zijn ouderen op die manier in staat het positieve van twee werelden - werk en privé - te combineren. Daartegenover staat een groep in een minder 
rooskleurige positie. Zij voelen een noodzaak om door te starten na (vervroegde) uittreding, maar worden gehinderd in de toegang tot werk. De werkloosheid onder ouderen is relatief hoog (15) en een aanzienlijke deel van de oudere werkzoekenden is langdurig werkloos. Dit staat op gespannen voet met de mogelijk toenemende noodzaak om door te werken uit financiële noodzaak, nu steeds meer gunstige uittredingsregelingen zijn versoberd of zijn opgeheven.

Bij dit onderzoek zijn enkele kanttekeningen te plaatsen. Allereerst moet worden opgemerkt dat de gegevens niet direct generaliseerbaar zijn. De steekproef omvatte oudere werknemers van een beperkt aantal, grote organisaties en is dus niet zonder meer een representatieve afspiegeling van de totale populatie van oudere werknemers in Nederland. Het is voorstelbaar dat de mate waarin de pensioentransitie als onvrijwillig wordt ervaren verschilt voor werknemers van grote en kleine bedrijven; in kleine bedrijven is er wellicht meer ruimte voor persoonlijke ondersteuning om de negatieve gevolgen van een gedwongen vertrek voor het welbevinden te verzachten. Bovendien is er meer onderzoek nodig om de invloed van pensionering op het welbevinden te onderzoeken voor zelfstandig ondernemers. Een tweede kanttekening betreft de motieven van gepensioneerden om door te starten. In de beschikbare data waren alleen gegevens bekend over het belangrijkste motief om weer te gaan werken. Het is echter zeer waarschijnlijk dat ouderen meerdere motieven hebben om door te werken na pensioen (16). Vervolgonderzoek zou zich daarom kunnen richten op de mate waarin verschillende motieven tezamen het doorstartgedrag en de consequenties daarvan beïnvloeden.

De resultaten van deze studie suggereren dat de transitie naar volledig pensioen zowel positief als negatief kan uitpakken voor het welbevinden van (vervroegd) gepensioneerden. De mate waarin ouderen hun arbeidsloopbaan en het afscheid van werk naar eigen preferentie vorm kunnen geven blijkt hierbij van belang te zijn. In de voorbereiding op het pensioen lijkt het dus belangrijk te zijn om realistische wensen en verwachtingen te formuleren en te kijken hoe men deze na pensioen in praktijk kan brengen. Een belangrijke rol is weggelegd voor leidinggevenden, $\mathrm{P} \& \mathrm{O}$-medewerkers en psychologen die oudere werknemers kunnen adviseren en ondersteunen in de voorbereiding op de transitie naar volledig pensioen. 


\section{Dankbetuigingen:}

Dit werk is ondersteund door een beurs van NWO - MaGW Onderzoekstalent [406-11-029] die is toegekend aan Kène Henkens en Ellen Dingemans. 


\section{Literatuur}

1. Henkens K, Van Solinge H, Van Dalen HP. Doorwerken over de drempel van het pensioen. Amsterdam: Amsterdam University Press; 2013.

2. Dingemans E, Henkens K, Van Solinge H. Doorstarten na pensioen: een opkomend fenomeen. Demos. 2013;29(8):1-3.

3. Szinovacz ME, Davey A. Predictors of Perceptions of Involuntary Retirement. The Gerontologist. 2005;45(1):36-47.

4. Van Solinge H, Henkens K. Adjustment to and Satisfaction With Retirement: Two of a Kind? Psychology and aging. 2008;23(2):422-34.

5. Quine S, Wells Y, De Vaus D, Kendig H. When choice in retirement decisions is missing: qualitative and quantitative findings of impact on well-being. Australasian Journal of Ageing. 2007;26(4):173-9.

6. Wang M, Zhan Y, Liu S, Shultz KS. Antecedents of Bridge Employment: A Longitudinal Investigation. Journal of Applied Psychology. 2008;93(4):818-30.

7. Lim VKG, Feldman DC. The impact of time structure and time usage on willingness to retire and accept bridge employment. The International Journal of Human Resource Management. 2003;14(7):1178-91.

8. Atchley RC. Continuity theory, self, and social structure. In: Ryff CD, Marshall VW, editors. Families and retirement Newbury Park, CA: Sage; 1999. p. 145-58.

9. Dendinger VM, Adams GA, Jacobson JD. Reasons for working and their relationship to retirement attitudes, job satisfaction and occupational self-efficacy of bridge employees. International Journal of Aging and Human Development. 2005;61(1):21-35.

10. CBS Statline. Van arbeid naar pensioen; personen 55 jaar of ouder. 2012.

11. Henkens K. Een sociologisch perspectief op langer werken. TPEdigitaal. 2011;5(2):36-52.

12. Diener E, Emmons RA, Larsen RJ, Griffin S. The Satisfaction With Life Scale. Journal of Personality Assessment. 1985;49(1):71-4.

13. Finkel SE. Causal analysis with panel data. Lewis-Beck MS, editor. Thousand Oaks, CA: Sage Publications, Inc; 1995.

14. Karpinska K, Henkens K, Schippers J. The recruitment of early retirees: A vignette study of the factors that affect managers' decisions. Ageing and Society. 2011;31(4):570-89.

15. UWV. UWV Arbeidsmarktprognose 2012-2013. 2012 juni 2012.

16. Kanfer R, Beier ME, Ackerman PL. Goals and motivation related to work in later adulthood: An organizing framework. European Journal of Work and Organizational Psychology. 2013;22(3):253-64. 
Tabel 1. Beschrijvende statistieken van de onderzoeksgroep.

Welbevinden na pensioen (schaal van 1 tot 5)

$\% / \mathrm{M}^{\mathrm{a}} \quad \mathrm{SD}$

$3,67 \quad 0,62$

Persoonlijke kenmerken

Welbevinden voor pensioen (schaal van 1 tot 5)

$3,71 \quad 0,61$

Leeftijd (55-70 jaar)

$61,55 \quad 2,83$

Vrouw

25

Gezondheidsproblemen

Geen problemen voor en na pensioen $\quad 58$

Problemen voor en na pensioen $\quad 17$

Negatieve verandering 9

Positieve verandering $\quad 15$

Verwacht pensioengat 41

Samenstelling van het huishouden

Partnerstatus

Samen met partner voor en na pensioen $\quad 82$

Alleenstaand voor en na pensioen $\quad 11$

Verlies van partner $\quad 5$

Nieuwe partner 2

Kinderen (t.o.v. geen kinderen) 85

Werkomgeving voor pensioen

Tevredenheid met de baan (schaal van 1 tot 5) $\quad 3,93 \quad 0,88$

Leidinggevende positie 28

Niveau van de baan

Laag niveau

Tijd sinds uittrede (0-6 jaar) 2,64

Kenmerken van het pensioneringsproces

Onvrijwillig uittreden

Doorstarten

Volledig pensioen zonder overweging tot doorstarten

Volledig pensioen, niet succesvol in het vinden van doorstartwerk

Actief in doorstartwerk

19

Doorstartwerk in het verleden

Bron data: NIDI Werk en Pensioen Panel (2001-2011), N = 1248.

${ }^{a}$ Percentages, tenzij anders aangegeven. Bij de schalen voor welbevinden en baantevredenheid geeft een hoge score (5) een hoge mate van welbevinden of tevredenheid aan. 
Tabel 2. Conditionele veranderingsmodel in de verklaring van welbevinden na pensioen op basis van de samenhang tussen onvrijwillig uittreden en doorstarten na pensioen ${ }^{a}$.

\begin{tabular}{llc}
\hline & $\mathrm{b}$ & $\mathrm{SE}$ \\
\hline Kenmerken van het pensioneringsproces & & \\
Doorstartwerk in verleden & $-0,01$ & 0,06 \\
Pensioentransitie & \multicolumn{2}{c}{ referentiegroep } \\
Vrijwillig uitgetreden - Niet meer gezocht naar doorstartwerk & $-0,13^{\dagger}$ & 0,08 \\
Vrijwillig uitgetreden - Niet succesvol in het vinden van doorstartwerk & 0,02 & 0,05 \\
Vrijwillig uitgetreden - Actief in doorstartwerk & $-0,24^{* *}$ & 0,04 \\
Onvrijwillig uitgetreden - Niet meer gezocht naar doorstartwerk & $-0,27^{* *}$ & 0,07 \\
Onvrijwillig uitgetreden - Niet succesvol in het vinden van doorstartwerk & $-0,09$ & 0,07 \\
Onvrijwillig uitgetreden - Actief in doorstartwerk & & \\
\hline
\end{tabular}

Bron data: NIDI Werk en Pensioen Panel (2001-2011), N = 1248 .

$\dagger p \leq .0 .10 ; * p \leq 0.05 ; * * p \leq .0 .01$.

${ }^{a}$ Gecontroleerd voor welbevinden voor pensioen, tijdstip meting pensioen, leeftijd, geslacht, gezondheidsproblemen, verwacht pensioengat, partnerstatus, kinderen, tevredenheid met de baan, leidinggevende positie, niveau van de baan, tijd sinds uittrede, doorstartwerk in het verleden en de vrijwilligheid van uittrede.

Opmerking: Missende waarden (1,2\%) binnen de persoonlijke kenmerken, samenstelling van het huishouden en de werkomgeving voor pensioen zijn geïmputeerd. Dit heeft de resultaten niet substantieel veranderd. 
Tabel 3. Conditionele veranderingsmodel in de verklaring van welbevinden na pensioen (1-5) op basis van de motieven voor doorstarten, gecontroleerd voor de overige determinanten ${ }^{a}$.

\begin{tabular}{llc}
\hline & $\mathrm{b}$ & $\mathrm{SE}$ \\
\hline Doorstarten & \multicolumn{2}{c}{} \\
Volledig pensioen, niet meer gezocht naar doorstartwerk & \multicolumn{2}{c}{ referentiegroep } \\
Volledig pensioen, niet succesvol in het vinden van doorstartwerk & $-0,11^{\dagger}$ & 0,06 \\
Actief in doorstarter: motieven & $-0,24^{* *}$ & 0,09 \\
Financiële reden & $0,11^{*}$ & 0,05 \\
Plezier in werk & 0,01 & 0,11 \\
Sociaal contact & 0,02 & 0,11 \\
Anders & $0,20^{\dagger}$ & 0,11 \\
Geen gegevens &
\end{tabular}

Bron data: NIDI Werk en Pensioen Panel (2001-2011), N = 1248 .

$\dagger p \leq .0 .10 ; * p \leq 0.05$

${ }^{a}$ Gecontroleerd voor welbevinden voor pensioen, tijdstip meting pensioen, leeftijd, geslacht, gezondheidsproblemen, verwacht pensioengat, partnerstatus, kinderen, tevredenheid met de baan, leidinggevende positie, niveau van de baan, tijd sinds uittrede, doorstartwerk in het verleden en de vrijwilligheid van uittrede.

Opmerking: Missende waarden (1,2\%) binnen de persoonlijke kenmerken, samenstelling van het huishouden en de werkomgeving voor pensioen zijn geïmputeerd. Dit heeft de resultaten niet substantieel veranderd. 


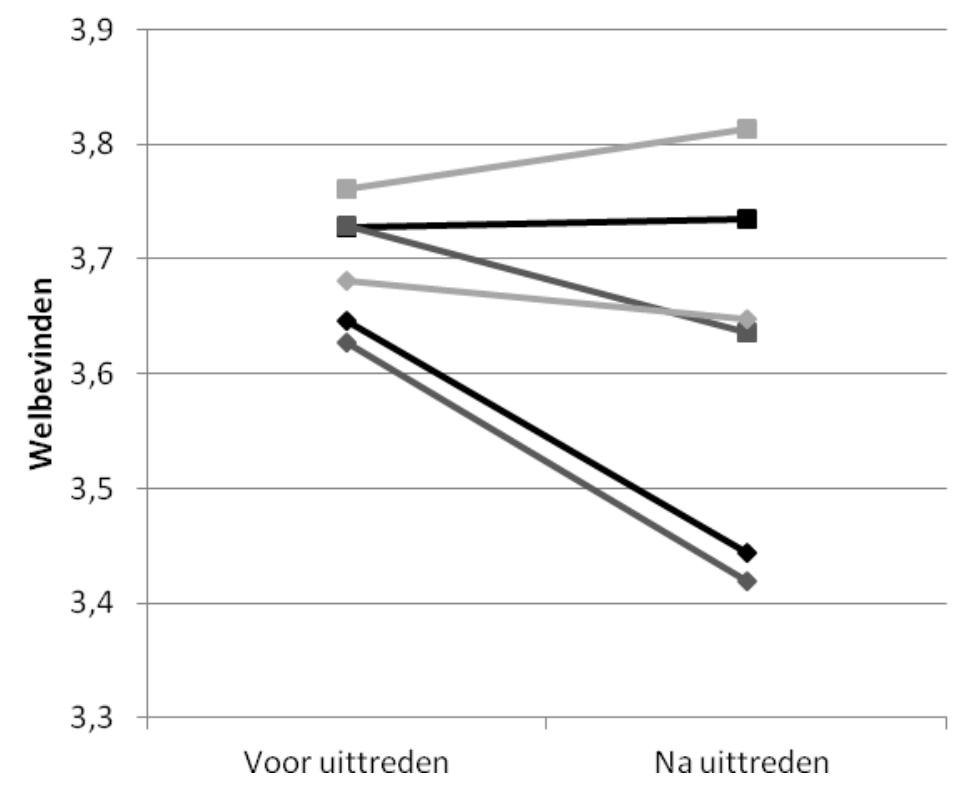

$\rightarrow$ Vrijwillig uitgetreden niet meer gezocht naar doorstartwerk

- -Vrijwillig uitgetreden geen doorstartwerk gevonden

- -Vrijwillig uitgetreden actief in doorstartwerk

- Onvrijwillig uitgetreden niet meer gezocht naar doorstartwerk

—Onvrijwillig uitgetreden geen doorstartwerk gevonden

$\_$Onvrijwillig uitgetreden actief in doorstartwerk

Figuur 1. Ongewogen gemiddelde niveau van welbevinden voor en na uittrede naar gelang de vrijwilligheid van pensioen en het doorstartgedrag.

Bron data: NIDI Werk en Pensioen Panel (2001-2011), N = 1248. 


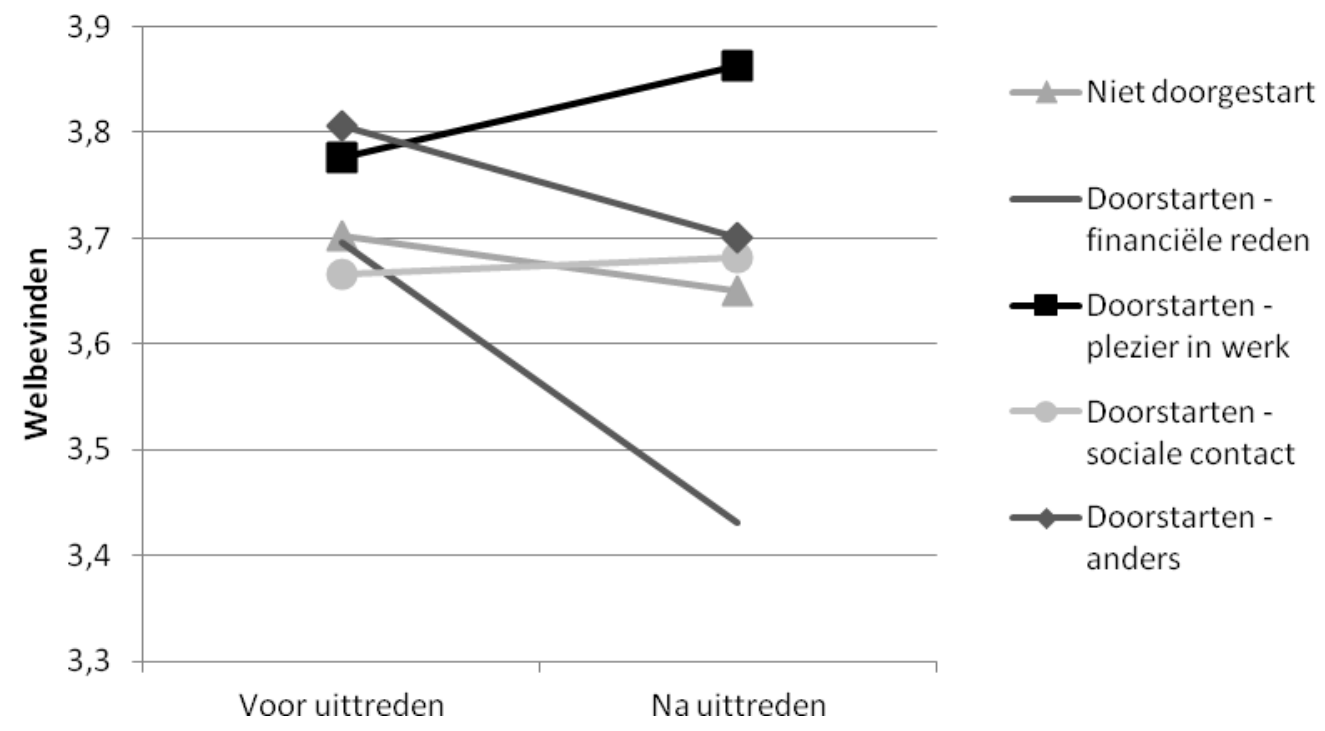

Figuur 2. Ongewogen gemiddelde niveau van welbevinden voor en na uittreden afhankelijk van het motief om door te starten.

Bron data: NIDI Werk en Pensioen Panel (2001-2011), N = 1248. 
Bijlage: Gebruikte meetinstrumenten voor de overige determinanten.

\begin{tabular}{|c|c|c|}
\hline & Codering & Vraagstelling \\
\hline Leeftijd & $\begin{array}{l}\text { Continue variabele: range } 55-70 \\
\text { Leeftijd op eerste meetmoment na pensioen. }\end{array}$ & Gegevens via werkgever \\
\hline Geslacht & $\begin{array}{l}\text { Dummy variabele: } \\
0=\text { man, } 1=\text { vrouw }\end{array}$ & Gegevens via werkgever \\
\hline $\begin{array}{l}\text { Gezondheids- } \\
\text { problemen }\end{array}$ & $\begin{array}{l}\text { Variabele met vier categorieën: } \\
\text { 1. geen gezondheidsproblemen tijdens } \\
\text { pensioentransitie } \\
\text { 2. gezondheidsproblemen voor en na } \\
\text { pensioen } \\
\text { 3. Gezondheidsverslechtering tijdens } \\
\text { pensioentransitie } \\
\text { 4. Gezondheidsverbetering tijdens } \\
\text { pensioentransitie }\end{array}$ & $\begin{array}{l}\text { Gevraagd op alle drie de meetmomenten: } \\
\text { Hebt u doorlopende gezondheidsklachten? } \\
\text { 1.nee, } 2 . \text { ja. }\end{array}$ \\
\hline $\begin{array}{l}\text { Verwacht } \\
\text { pensioengat }\end{array}$ & $\begin{array}{l}\text { Dummy variabele: } \\
0=\text { nee, } 1=\mathrm{ja} / \text { weet niet }\end{array}$ & $\begin{array}{l}\text { Gevraagd op meetmoment } 1 \text { : } \\
\text { Denkt } u \text { dat } u \text { een pensioengat hebt opgelopen } \\
\text { tijdens uw loopbaan? } \\
\text { 1. nee, } 2 \text {. ja, } 3 \text {. weet niet. }\end{array}$ \\
\hline Partnerstatus & $\begin{array}{l}\text { Variabele met vier categorieën: } \\
\text { 1. samenleven met partner voor en na } \\
\text { pensioen } \\
\text { 2. geen partner (niet samenleven) voor en na } \\
\text { pensioen } \\
\text { 3. verlies van een partner tijdens de } \\
\text { pensioentransitie } \\
\text { 4. nieuwe partner tijdens de } \\
\text { pensioentransitie }\end{array}$ & $\begin{array}{l}\text { Gevraagd op alle drie de meetmomenten: } \\
\text { [1] Wat is uw burgerlijke staat? a. gehuwd, b. } \\
\text { gescheiden, 3. weduwe/weduwnaar, } 4 . \\
\text { ongehuwd. } \\
\text { [2] Hebt u een partner? a. nee, b. ja, woon } \\
\text { samen met partner, c. ja, maar woon niet } \\
\text { samen met partner. }\end{array}$ \\
\hline Kinderen & $\begin{array}{l}\text { Dummy variabele: } \\
0=\text { nee, } 1=\mathrm{ja}\end{array}$ & $\begin{array}{l}\text { Gevraagd op meetmoment } 1 \text { : } \\
\text { Heeft u kinderen? 1. nee, 2. ja. }\end{array}$ \\
\hline $\begin{array}{l}\text { Tevredenheid } \\
\text { met de baan }\end{array}$ & $\begin{array}{l}\text { Quasi-interval variabele: range } 1-5 \text {. } \\
\text { Antwoordcategorieën gespiegeld. }\end{array}$ & $\begin{array}{l}\text { Gevraagd op meetmoment } 1 \text { : } \\
\text { Hoe tevreden bent } \mathrm{u} \text { met het werk dat } \mathrm{u} \\
\text { momenteel doet? } \\
\text { 1. heel tevreden }-5 \text {. heel ontevreden }\end{array}$ \\
\hline $\begin{array}{l}\text { Leidinggevende } \\
\text { positie }\end{array}$ & $\begin{array}{l}\text { Dummy variabele: } \\
0=\text { nee, } 1=\text { ja }\end{array}$ & $\begin{array}{l}\text { Gevraagd op meetmoment } 1 \text { : } \\
\text { Heeft u een leidinggevende functie? } \\
\text { 1. nee, } 2 . \text { ja, ik geef leiding aan } 1-9 \\
\text { medewerkers, 3. ja, ik geef leiding aan } 10-19 \\
\text { medewerkers, } 4 \text {. ja, ik geef leiding aan meer } \\
\text { dan } 20 \text { medewerkers. }\end{array}$ \\
\hline $\begin{array}{l}\text { Niveau van de } \\
\text { baan }\end{array}$ & $\begin{array}{l}\text { Variabele met drie categorieën: } \\
\text { Laag niveau }(1,2,3) \\
\text { Gemiddeld niveau }(4,5) \\
\text { Hoog niveau }(6,7)\end{array}$ & $\begin{array}{l}\text { Gevraagd op meetmoment } 1 \text { : } \\
\text { Welk opleidingsniveau is momenteel vereist } \\
\text { voor het werk dat u doet? } \\
\text { 1. lagere school, } 2 \text {. lager beroepsonderwijs, } 3 \text {. } \\
\text { mavo, } 4 \text {. middelbaar beroepsonderwijs, } 5 \text {. } \\
\text { havo/vwo, } 6 \text {. hoger beroepsonderwijs, } 7 \text {. } \\
\text { universiteit }\end{array}$ \\
\hline $\begin{array}{l}\text { Tijd sinds } \\
\text { uittrede }\end{array}$ & Continue variabele: range $0-6$. & $\begin{array}{l}\text { Gevraagd op meetmoment } 2 \text { en } 3 \text { : } \\
\text { In welk jaar bent u gestopt? }\end{array}$ \\
\hline
\end{tabular}

